\title{
Digital Technologies as a Factor in Reducing the Impact of Quarries on the Environment
}

\author{
Mikhail ZARUBIN ${ }^{*}$, Venera ZARUBINA ${ }^{2}$, Kadyrgali JAMANBALIN $^{3}$, \\ Darkhan AKHMETOV ${ }^{4}$, Zhaukhar YESSENKULOVA ${ }^{5}$, Rassima SALIMBAYEVA ${ }^{6}$ \\ ${ }^{1,2}$ Rudny Industrial Institute, Rudny, 111500, Republic of Kazakhstan \\ ${ }^{3}$ Kostanay Social and Technical University named after Z. Aldamzharova, Kostanay, 111000 , \\ Republic of Kazakhstan \\ ${ }^{4}$ Kostanay Engineering and Economic University named after M. Dulatov, Kostanay, 111000, \\ Republic of Kazakhstan \\ ${ }^{5,6}$ Non-profit joint stock company 'Narxoz University', Almaty, 050035, Republic of Kazakhstan
}

\begin{abstract}
The industrial development of mankind is based on the intensive use of natural resources of the planet. The development of the mining industry is a necessary and important factor for the successful development of the national economy. At the same time, mining has a significant impact on environmental degradation. Methods for assessing and minimizing the environmental impact of mining have only been developed in practice in the last 50 years and differ significantly from country to country. The article analyses the approaches and methodologies for environmental impact assessment (EIA) based on international and national standards. The methods used in Kazakhstan and the countries of the EuropeanAsian Economic Union (EurAsEU) are critically evaluated. The developed mathematical models are implemented in the form of digital solutions and implemented in the module of the cloud system '3D Quarry'. The methodology proposed by the authors for use and the developed software product allow optimizing mining operations at quarries according to the parameters of minimizing their negative impact on the environment. At the same time, it is mandatory to comply with mandatory national and international regulations. The proposed 3D Quarry system and the EIA module are an alternative to commercial software products (and their pirated copies, often used by companies in the countries under study) and are aimed at small mining companies in post-Soviet countries. It is expected that the application of the proposed software product will allow, within the technological capabilities, to minimize the impact of quarries on the environment of Kazakhstan.
\end{abstract}

Keywords - Ecology; environmental impact assessment; information system; intelligent management; Quarry

\section{INTRODUCTION}

The rapid growth of the world's population also leads to a significant increase in the consumption of natural resources, which is accompanied not only by a change in the quantitative scale of anthropogenic impact, but also by the emergence of new factors. The damage caused to natural components leads to already tangible environmental consequences.

\footnotetext{
* Corresponding author.

E-mail address: zarubin_mu@mail.ru
} 
The influence of man on nature in the twentieth century led to significant environmental problems. The twenty-first century is already characterized by a progressive environmental crisis and a continuing intensification of human impact on the environment.

The analysis of the state of only the mineral resource base of the mining and metallurgical complex of Kazakhstan indicates its significant expansion in the expected years. Thus, at present, 38 lead and zinc deposits ( $88.7 \%$ of total zinc reserves, $66.8 \%$ of lead reserves), 15 iron ore deposits $(26.1 \%), 46$ copper deposits $(58.8 \%), 90$ gold ore deposits and 39 complex gold-bearing deposits $(86 \%)$ have already been recognized as active.

At the same time, in the process of mining production, spaces are formed and rapidly increase, which are disturbed by mining workings, dumps of rocks and processing waste, and represent barren surfaces. A significant disadvantage of the development of open mineral deposits is the negative impact on the environment, expressed in the impact on the atmospheric air, on surface and underground water, on land resources, etc. This all manifests itself in the suppression and destruction of natural vegetation, migration and reduction of the number of wild animals, reduced productivity of agriculture and forestry, animal husbandry and fisheries [1].

In almost all countries of the world, mining companies are currently required to develop measures to reduce negative environmental impacts and risks in order to obtain a license for subsurface use. Mining companies are forced to conduct more and more in-depth and expensive research to develop and implement measures to minimize the negative impact on the environment. Therefore, the EIA already plays an important role in quantifying the sustainability of mining operations [2].

At the same time, it should be noted that the historical approaches of the EIA in the socalled countries of the 'post-Soviet' and 'Western' world differ significantly both in methodological and legislative aspects. Naturally, this creates difficulties and risks, especially for small companies operating in this sector of the economy.

One of the strategic priorities of the Republic of Kazakhstan is the implementation of an effective state environmental policy and environmental protection. In his address to the people of Kazakhstan, President Tokayev stressed that environmental protection and environmental development are at the forefront of Kazakhstan's agenda. The whole civilized world is engaged in this issue [3]. Achieving these goals requires a comprehensive and responsible state environmental policy, which, on the one hand, should be consistent with the global Sustainable Development Goals, and on the other hand, should ensure the effective integration of global and national priorities.

In such conditions, the importance of environmental protection for the enterprise needs prompt, reliable and complete information. In this regard, automation issues are of great strategic importance, since in the future the results of activities in the field of environmental protection will depend not only on the state of the material base, the qualifications of personnel, but also on the reliability and efficiency of the presentation of all environmental information.

Considering the currently available capabilities of digital computing systems for modelling complex processes in real time, it is interesting, in our opinion, to dynamically solve these problems depending on constantly changing both technical and economic conditions. The second important factor is the development of optimized proposals for managing processes with minimal possible environmental impacts under current conditions.

The market for software for EIA is quite diverse and is represented by both freely distributed and proprietary software. However, there is a limited amount of research that offers software solutions for small project and mining companies that meet the requirements of both compliances with regulatory and legal requirements under the EIA, and the pricing 
capabilities of companies. With regard to reporting, in particular, very little research has been conducted in the context of Kazakhstan's mining industry.

The purpose of the study is to analyse the possibilities of merging international and national standards in the field of EIA for Kazakhstan and the EurAsEU countries using similar approaches. Based on the results obtained, it is proposed to develop a module for environmental assessment of the impact of quarries on the environment, program implementation of planning mechanisms for minimizing the impact of quarries in dynamically changing environmental conditions of the enterprise.

The methodological framework is implemented in the form of a cloud-based Software as Service (SaS) solution, which can be used by small project and mining companies as an alternative to expensive commercial software. For the development of the EIA software module, an analysis of existing EIA requirements and methods related to the impact of quarries on the atmosphere, water basin, earth and subsurface was carried out.

The research was carried out within the framework of the grant of the Ministry of Education and Science of the Republic of Kazakhstan IRN AP09561619 Development of the core of the web service '3D-quarry'.

\section{Methodologies}

The 3D-Quarry system developed by the team of authors involves the integration of the results and development of research conducted and conducted within the framework of initiative and grant research in the direction of 'Improving the efficiency of mining enterprises'. Within the framework of the system, it is planned to combine previously developed systems: 'Mining planning', 'Development of decision support systems for the formation of effective technological schemes for stabilizing the quality of minerals' [4], 'Hydrogeological calculations' and the developed module 'EIA'.

Principles of assessing the negative impact of quarries on the ecosystem are to select a maximum load the process on each of the components of the environment consumption of energy resources during normal and adverse weather conditions situations in comparison with the established standards of maximum permissible concentrations effects on human health, wildlife and vegetation, and recreational areas.

The main types of negative impact on the environment in the open-pit mining of mineral deposits are:

- pollution of the atmosphere by emissions of gaseous and suspended substances;

- noise exposure;

- withdrawal of natural resources (land, water);

- changing the landscape;

- changes in hydrogeological conditions; pollution of the environment by sewage and waste;

- impact on the animal and plant world;

- changing social conditions of the population [5].

Thus, the main impacts of quarries can be reduced to impacts on water and air basins, impacts on the earth and subsoil, impacts on flora and fauna. The modified structure of the web application '3D-quarry' taking into account the module 'EIA' received the form shown in Fig. 1. 


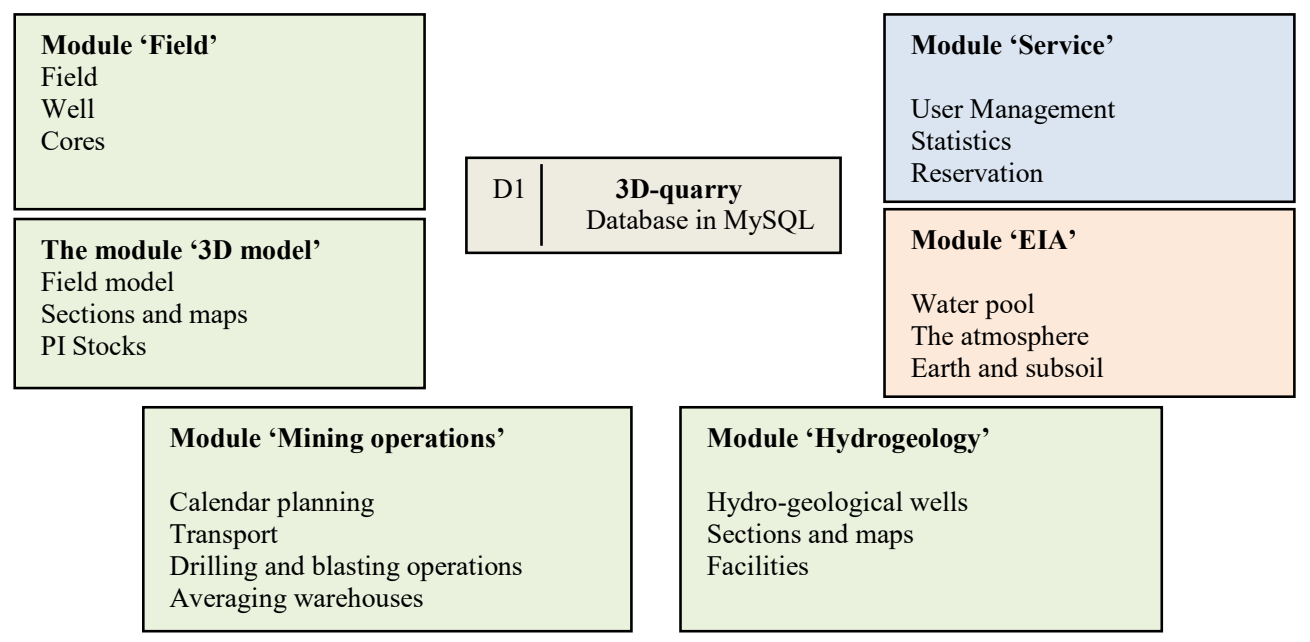

Fig. 1. Structure of the '3D-quarry' system with the integration of the 'EIA' module.

In the United States, environmental protection is based on the adopted National Environmental Policy Act (NEPA) and the adopted' Rules for the Implementation of EIA Procedures 'established by NEPA [6]. On the basis of NEPA, the legal services of individual US states develop their own rules for the implementation of EIA procedures. In Canada, in addition to the NEPA, the law 'On Environmental Assessment' has been adopted.

In the EU, legislative initiatives to protect the environment are based on UN Directive $85 / 337 /$ EEC for the member States of the European Economic Community (EEC) 'On the assessment of the environmental impact of certain public and private projects' [7]. On the basis of it, the EU countries and Japan developed their own legislative acts [8].

In Europe, regulation is carried out by the Environmental Management and Audit Scheme of the European Union EMAS.

The main international document is the international Convention 'On Environmental Impact Assessment in a Transboundary Context' [9]. The main provisions of these documents are presented in the form of international standards in the field of environmental activities of the ISO 14000 series. The requirements for the environmental management system are established by the international standard ISO 14001:2016. However, in Kazakhstan, these standards operate on the principle of voluntariness and are not mandatory.

It is worth noting that there are both significant similarities in the EIA procedure in the Republic of Kazakhstan and the EU (in particular, concerning public participation), and significant differences (for example, in the stages of the EIA) [10].

The legislative regulation of open-pit mining in Kazakhstan, as in most countries, is based on the Constitution, and regulated by codes. In Kazakhstan, the regulation is carried out by:

- The Code of the Republic of Kazakhstan dated 05.01.2021 'On subsoil and subsurface use' [11];

- The Environmental Code of the Republic of Kazakhstan dated 02.01.2021 [12];

- The Land Code of the Republic of Kazakhstan of June 20, 2003 [13];

- The Water Code of the Republic of Kazakhstan of July 9, 2003 [14].

If an international treaty ratified by the Republic of Kazakhstan establishes rules other than those contained in the Codes, the rules of the international treaty shall apply. 
Accordingly, the assessment methods used for the implementation must comply, firstly, with the current legislation of the country, and, secondly, at the request of the enterprise, comply with international EIA standards.

Accordingly, the assessment methods used for the implementation in different countries of the United States, the EU and the Eurasian Economic Community (for example, the Republic of Kazakhstan) must comply, firstly, with the current legislation of the country, and, secondly, at the request/desire of the enterprise, comply with international standards.

The study analyses the methods of environmental impact assessment (EIA) for the water basin, atmosphere, land and subsurface of existing mining enterprises.

The issues of wastewater treatment and rational use of water resources at industrial enterprises are considered in the works of many scientists: Ilyin [15], Gogin [16], Pavlov [17], Lesin [18], [19], Tyulenev [20] and others. Ensuring the environmentally feasible and sustainable implementation of infrastructure projects, the procedure for assessing the impact on the environment is considered in the works of Kalnins [21], Bajcinovci [22], [23], joint environmental management [15], optimization for the full use of bioresources [24]-[30].

The fundamental provisions on the main methods and technologies for managing dust and gas pollution of atmospheric air at mining enterprises are set out in the fundamental works of Rzhevsky [31], Trubetskoy [32], [33], Chanturia [34], etc.

Analysis of methods for assessing the impact on the water basin and regulatory documents allowed us to identify the methodology for determining the gross discharge of harmful substances into reservoirs by various types of quarry transport [35] as the most fully reflecting the impact on the water basin. The method does not contradict the requirements of the EIA and allows you to:

- calculate the pollution of wastewater provided that the wastewater is discharged into the reservoir from the estimated source with mixing with wastewater from other sources and the concentration of the $i$-th impurity in the wastewater entering the reservoir is not constant during the year;

- calculate the impact of various quarry transport on wastewater pollution;

- calculate pollution due to household needs of mining enterprises.

This method is chosen as the base for software implementation in the module for calculating the impact of quarries on the water basin.

Determination of the qualitative and quantitative composition of the expected harmful emissions into the atmosphere during the operation of quarries in the Republic of Kazakhstan is carried out in accordance with the current regulatory and technical documents [35].

The analysis allows us to state that the methods allow us to produce:

- calculation of emissions of pollutants from quarry equipment and road transport when burning diesel fuel;

- calculation of dust emissions during excavation of rock mass during excavation and loading operations;

- calculation of dust emissions when unloading overburden into the dump;

- calculation of dust formation during road transport operations;

- calculation of the gaseous emissions in the manufacture of blasting;

- calculation of the emissions during drilling operations with dry cleaning devices.

At the same time, the method of calculating harmful emissions for a complex of open-pit mining equipment (based on specific indicators) is most often used [36], [37]. Its advantage is that it allows you to calculate atmospheric air pollution during blasting operations for individual substances, determine the mass of harmful gases remaining in the exploded rock mass and calculate the mass of solid particles released from the dust and gas cloud. 
This method is chosen as the basic one for software implementation in the module for calculating the impact of quarries on the atmosphere.

Similarly, the analysis of methods for calculating the impact of mining workings on the subsurface allowed us to identify a method for software implementation in the ' $3 \mathrm{D}$-quarry' system as a submodule of 'EIA: The bowels'.

When studying the tasks of the EIA, especially of a predictive nature, the characteristic features are the need to analyse a large number of influencing factors and, often, the lack of initial data. In such a situation, there is a need to use additional methods of mathematical apparatus: correlation analysis, approximation of dependencies, probabilistic analysis. Naturally, this significantly increases the cost of calculations, and reduces their accuracy. At the same time, the development of the section of neural networks suggests that such control systems can be developed and effective precisely on artificial neural networks (INS), since neural networks are focused on processing large amounts of information (including weakly structured), are capable of learning and adaptation. However, today, and for the application of artificial neural networks there are unresolved issues.

The basis of the theory of artificial neural networks is laid in the works of McCulloch, Pitts, Hebb, Rosenblatt, Hubel, Wiesel, Widrow, Steinbuch, Minsky, Hopfield, Amosov, Galushkin, Levin, Litovchenko and others [38]-[40].

This thread is dedicated to the publication of such foreign authors as P. Spek, L. Patterson, R. Bishop, George of Dutch. The theoretical aspects of artificial neural networks are quite well developed by such well-known Ukrainian and Russian researchers as Amosov, Belov, Kussul, Glushkov, Galushkin, Gorban, Dunin-Barkovsky, Mirkes, Tsaregorodtsev, Barsky and others. In the scientific and technical literature of the Republic of Kazakhstan, the problems associated with the apparatus of artificial neural networks are considered in the works of Tsekhovoy, Akhmedov, Makarenko, Yavorsky [41]-[44] and many others.

In the study for the implementation of the forecasting mechanisms used by the typical architecture of the neural networks: multilayer network (multilayer perceptron) and a network of radial basis functions.

\section{Development of THe EIA Module}

According to the analysis, the EIA methods used for the implementation must comply, firstly, with the current legislation of the country, and, secondly, at the request of the enterprise, comply with international EIA standards.

The article systematizes the results of the impact of mining production on the environment for individual elements of the biosphere, Table 1.

The selected conceptual solutions define the system as a cloud-based web application, which imposes its own limitations on the development tools of this information system and involves the use of web-based development tools.

Although development tools, such as high-level languages, allow you to develop cloud products, however, they require significantly more time resources for implementation due to a different orientation.

The accepted division of the resource functionality into the server side of the interface (back-end) and the client side of the interface (front-end) of the web resource also imposes restrictions on the development tools. 
TABLE 1. MAIN TyPES AND RESUlts OF THE IMPACT OF MINING ON THE BIOSPHERE

\begin{tabular}{|c|c|c|}
\hline $\begin{array}{l}\text { Elements of } \\
\text { the biosphere }\end{array}$ & Impact on the elements of the biosphere & Impact result \\
\hline $\begin{array}{l}\text { Water pool, } \\
\text { underground } \\
\text { water }\end{array}$ & $\begin{array}{l}\text { Field drainage, discharge of waste and } \\
\text { drainage water }\end{array}$ & $\begin{array}{l}\text { Reduction of underground, ground and surface } \\
\text { water reserves. Violation of the hydrogeological } \\
\text { and hydrological regimes of the water basin }\end{array}$ \\
\hline $\begin{array}{l}\text { Water pool, } \\
\text { surface water }\end{array}$ & $\begin{array}{l}\text { Drainage and transfer of surface reservoirs } \\
\text { and watercourses, discharge of waste and } \\
\text { drainage water, water intake for technical } \\
\text { and household needs of enterprises }\end{array}$ & $\begin{array}{l}\text { Pollution of the water basin by sewage and } \\
\text { drainage waters. Deterioration of water quality as } \\
\text { a result of adverse changes in hydrochemical and } \\
\text { biological regimes of surface and underground } \\
\text { waters }\end{array}$ \\
\hline Air pool & $\begin{array}{l}\text { Organized and unorganized emissions of } \\
\text { dust and gases into the atmosphere }\end{array}$ & Contamination (dust and gas contamination) day \\
\hline $\begin{array}{l}\text { Lands and } \\
\text { soils }\end{array}$ & $\begin{array}{l}\text { Mining operations, construction of dumps, } \\
\text { hydraulic dumps, tailings and reservoirs. } \\
\text { Construction of industrial and civil buildings } \\
\text { and structures. Laying of roads and other } \\
\text { types of communications }\end{array}$ & $\begin{array}{l}\text { Deformation of the earth's surface. Violation of } \\
\text { the soil cover. Reducing the area of productive } \\
\text { land. Deterioration of soil quality. Changing the } \\
\text { appearance of the territory. Changes in the state } \\
\text { of ground and surface waters. Deposition of dust } \\
\text { and chemical compounds due to emissions into } \\
\text { the atmosphere. Erosion }\end{array}$ \\
\hline $\begin{array}{l}\text { Flora and } \\
\text { fauna }\end{array}$ & $\begin{array}{l}\text { Industrial and civil engineering. } \\
\text { Deforestation. Violation of the soil cover. } \\
\text { Changes in the state of ground and surface } \\
\text { waters. Dust and gas pollution of the } \\
\text { atmosphere. Industrial and household noise }\end{array}$ & $\begin{array}{l}\text { Deterioration of the habitat conditions of forest, } \\
\text { steppe and aquatic flora and fauna. Migration and } \\
\text { decline in the number of wild animals. } \\
\text { Suppression and reduction of wild plant species. } \\
\text { Decrease in the yield of agricultural crops. } \\
\text { Reduced productivity of livestock, fish and } \\
\text { forestry }\end{array}$ \\
\hline Subsurface & $\begin{array}{l}\text { Conducting mining operations. Extraction } \\
\text { of minerals, host and overburden rocks. } \\
\text { The drainage fields. Flooding of the field } \\
\text { areas. Ignition of minerals and waste } \\
\text { rocks. Disposal of harmful substances and } \\
\text { industrial waste. The discharge of } \\
\text { wastewater }\end{array}$ & $\begin{array}{l}\text { Changes in the stress-strain state of a rock } \\
\text { mass. Reduction in the quality of minerals and } \\
\text { the industrial value of deposits. Pollution of } \\
\text { the subsoil. Development of karst processes. } \\
\text { Mineral losses due to dilution }\end{array}$ \\
\hline
\end{tabular}

Based on the results of the analysis, out of a possible set of software resources, it was decided to use:

- for the implementation of the back - end-server scripting programming language php;

- for front-end - multi-paradigm programming language javascript, javascript framework jQuery and asynchronous data exchange technology Ajax.

It was decided to abandon the use of other tools and frameworks.

For the implementation of the data warehouse, the analysis of freely distributed weboriented DBMS is carried out. It was decided to abandon the use of proprietary DBMS immediately for commercial reasons. The analysis of the compliance of the DBMS capabilities allowed us to identify and select the MySQL relational DBMS as one of the most common for web projects.

For the implementation of the module, the structure of the relational database of the 3D Quarry system has been finalized. 14 new tables have been added to the database for implementing the functions of the 'EIA' module (changes in the structure of the application administration service tables are not displayed). A fragment of the datalogical model showing the changes made is shown in Fig. 2. 


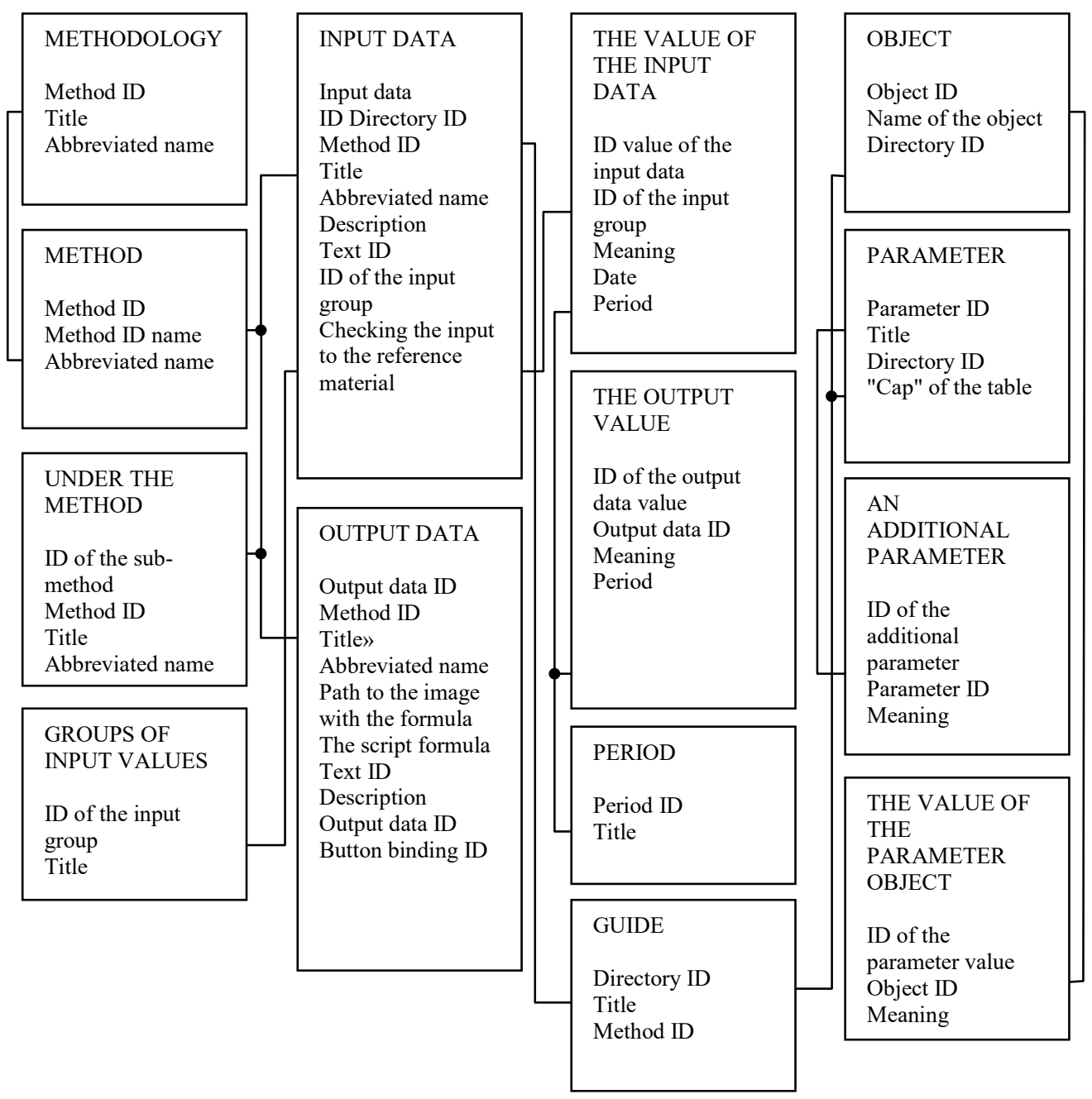

Fig. 2. Additions to the logical model of the data structure for the 'EIA' module.

The physical structure of the database is implemented in the MySQL database management system. In connection with the preparation of security documents for the developed system ' $3 \mathrm{D}$-quarry', the physical structure of the database is not disclosed in this document.

Algorithmically, the methods are implemented in php and javascript:

- calculation of harmful emissions for the complex of open-pit mining equipment (based on specific indicators);

- determination of gross discharges of harmful substances into water bodies by various types of quarry transport;

- calculation of the negative impact of the quarry on the subsoil and land.

When developing an algorithm for measures to reduce the negative impact on atmospheric air, all measures can be divided into three groups: 1) Replacing existing technology and equipment with more environmentally friendly ones; 2) Equipping and retrofitting of technological equipment with gas cleaning plants (GOU); 3) More efficient use of the scattering capacity of the atmosphere. 
To reduce the negative impact on the atmospheric air during mining operations, it is necessary to carry out the following measures:

- moisten dirt roads, mining ledges and dumps in the dry and hot season;

- carry out refuelling and maintenance of mobile equipment at the nearest gas station, or at a slightly remote private base with a hard surface;

- to monitor the compliance of vehicle exhaust emissions before leaving the construction site in accordance with the established technical standards;

- collect and temporarily store waste in specialized containers and containers with subsequent transfer to enterprises that have a license to process, neutralize or dispose of solid household waste (MSW) at a landfill.

Environmental protection measures should also include the implementation of regulatory requirements for the greening of sanitary protection zones - at least $50 \%$ of the SPZ around quarries, with the mandatory organization of a strip of tree and shrub plantations (at least 50 $\mathrm{m}$ ) on the side of residential development. Transport and communication lanes should occupy $3-5 \%$ of the total area of the SPZ. At the border of the sanitary protection zone, it is necessary to monitor the main parameters of environmental pollution: the level of atmospheric air pollution, noise level, water quality in water bodies, soil pollution.

The size of the established sanitary protection zone can be reduced by reducing the content of harmful substances in the atmospheric air to an acceptable level as a result of environmental protection measures.

As measures preventing the occurrence of an emergency in the quarry (spill of gasoline from the gas tank of vehicles and machinery), it is recommended to carry out technical inspection of vehicles before leaving the site, conduct timely repair and replacement of spent consumables (oil, filters, etc.) and have become unusable parts and components of equipment.

As constructive measures to prevent the occurrence of a fire, in addition to placing an emergency fuel drain tank, it is recommended to equip the sites with a supply of water for fire extinguishing.

Accordingly, the inclusion of the EIA module should also have an impact on the mining design modules, for example, planning green areas when designing a quarry.

The design of mining operations in quarries located near water bodies is carried out in compliance with the conditions of the regime of water protection zones of watercourses and the Water Code of the Republic of Kazakhstan.

Environmental protection measures in relation to surface waters include the following measures:

- mandatory collapse of the zone of the side ledge, which is the border of the coastal protective strip of the considered watercourse, which prevents surface runoff from the quarry;

- compliance with restrictive conditions when working in the water protection zone of the nearest watercourse;

- surface water monitoring, aimed at controlling the pollution of the watercourse during the period of trans-shipment operations within the sanitary protection zone;

- a rational water use regime that allows the use of imported water only for drinking needs and the intake of river water for irrigation of dirt roads only in dry and windy times;

- timely distribution of rainwater accumulated in the lower segments of the quarry over the entire overburden storage area;

- implementation of refuelling of quarry transport at specially equipped sites, vehicles-at the nearest organized gas station. 
Environmental protection measures in relation to groundwater include the following measures:

- carrying out mining operations to the full depth of extraction of raw materials only during the low-water period;

- storage of special equipment on the inner-pit areas with a hard surface, located above the sole of the processing of quarry stocks by $0.5-1.0 \mathrm{~m}$;

- implementation of refuelling of road equipment by a gas station attendant outside the quarry area, mobile vehicles - at public gas stations;

- exclusion of the collection and accumulation of production waste on the territory of the quarry mining site;

- installation of a bio-toilet with timely removal to the nearest existing treatment facilities;

- implementation of repair and maintenance of motor vehicles in specialized organizations;

- water intake from the flooded part of the underground water of the quarry by the pump of the irrigation washing machine in a limited volume and only in the windy and hot season;

- development of a monitoring system for open water bodies and aquifers;

- implementation of measures for the reclamation of the developed quarry areas in the direction of their subsequent use.

If the well is used as a source of water supply for the period of work, the area around the well $(4 \mathrm{~m})$ is filled with concrete, the access area to the structure $(16 \mathrm{~m})$ is reinforced with crushed stone. The territory of the first belt of the sanitary protection zone is planned with the diversion of surface runoff beyond its limits, fenced and secured. The wellhead is equipped with a sealed removable head and closed with a wooden overhead box. The water intake from the source is monitored by installing a flow meter to determine the actual flow rate of the pumped underground water. The well is provided for monitoring the underground water.

To reduce the negative impact on the soil, waste generated during the production of works is temporarily accumulated in metal containers on a specially designated area with a hard surface, followed by export to organizations that have licenses for their storage and disposal.

The lands disturbed during mining should be reclaimed in the direction of their subsequent use. Regardless of the direction of use, it is planned to re-cultivate the adjacent territory, which includes land for temporary use for auxiliary facilities of the object's infrastructure: storage sites for overburden dumps, and the placement of a shift camp.

Land reclamation is carried out in two stages: technical and biological. The technical stage includes the planning, the formation of slopes, the removal and application of a fertile layer of soil on re-cultivated land. In this regard, at the mining stage of reclamation, it is provided:

- the device of slopes at an angle of $15-45^{\circ}$;

- planning of the quarry floor and rock dumps;

- dumping of overburden to the bottom of quarry recesses;

- subsequent application of a fertile layer with a thickness of $0.25-0.3 \mathrm{~m}$ to the bottom, the slopes of the quarry sides and re-cultivated dumps;

- final layout of the reclaimed surface of the quarry.

After the completion of the technical stage of re-cultivation, the temporary use lands are transferred to the land users for the biological stage of re-cultivation according to the act in accordance with the established procedure. 
The biological stage of reclamation includes a complex of agrotechnical and biotechnical measures aimed at securing the soil from erosion, restoring the fertility necessary for the further use of the territory in the recreational direction.

Carrying out the biological stage according to the reclamation queues is allowed both immediately on the entire area assigned to the queue, and within individual sections as the technical stage is carried out.

The fertile layer is removed before the start of overburden work, followed by storage in burts on the previously re-cultivated site.

In accordance with the direction of reclamation-pasture lands - and the characteristics of the natural soil cover in the designated areas, after technical reclamation, the following scheme for restoring land fertility is proposed.

On the planned land area of the developed quarries, the potentially fertile and returned fertile layer with a capacity of $15-20 \mathrm{~cm}$ is loosened by harrowing, mineral fertilizers are applied and the grass or grass mixture that is zoned and characteristic of this type of soil is sown. Further, post-sowing uniform rolling with ringed rollers and planting of zoned shrub species, if necessary, is carried out. Biological re-cultivation should be carried out in the autumn period without one-time irrigation.

The restoration of the former composition of the natural phytocenosis will take place in three stages. The first stage includes the sowing of grasses, the second and third stages are the result of natural regenerative primary autogenic succession (the evolutionary development of vegetation within any zone), represented by a system of changes of some phytocenoses by others, with time intervals between stages 1-3 years. The projected yield already in the first year of the growing season makes it possible to restore the productivity of the land to the initial level. Thus, the pasture yield will be restored in the second year, the natural phytocenosis in 4-5 years from the beginning of biological reclamation. The transfer of reclaimed land to recreational land will be considered complete at least 3 years after the biological stage.

In the water management direction of using the quarry excavation of the developed areas of the field, at the end of the technical stage of reclamation, it is planned to create an artificial reservoir of complex purpose in it: for fish farming and recreational purposes; construction of appropriate hydraulic structures necessary for flooding the quarry excavation and maintaining the calculated level in them.

Overburden operations are carried out without first removing the soil layer due to its low humus content and high salinity. In the future, the lithostrats of existing dumps can be used as a potentially fertile layer during the biological stage of re-cultivation and greening of overburden dumps.

Technical remediation is carried out in parallel with mining operations, on the area of mining of the lower ledge, and within a year after the completion of mining operations (including on dumps).

The main requirements for the rational use and protection of mineral resources are:

- strict compliance with design decisions;

- maintaining the established geological survey documentation;

- ensuring and controlling the complete extraction of raw materials;

- reliable accounting of the reserves extracted and left in the subsurface, drawing up annual plans for the development of mining operations;

- protection of mineral deposits from flooding, flooding, fires and other factors that reduce the quality of minerals and the industrial value of deposits or complicate their development;

- not allowing excessive losses, dilution and selective mining of minerals; 
- compliance with the requirements for the safe conduct of mining operations related to the use of subsurface resources;

- the production of blasting operations below the level of underground water in a clamped environment, the development of minerals by the non-explosive method;

- prevention of subsurface pollution by industrial waste or wastewater.

Blasting operations carried out at mining enterprises cause a negative seismic impact on the production environment of enterprises and other protected objects. At present, the improvement of ways to improve the safety of technological processes and working conditions of workers with reasonable industrial development is of paramount importance, and the culture of blasting involves reducing the harmful effects of the consequences of an explosion.

According to the State Technical Supervision of the Republic of Kazakhstan, at the objects of mining, non-metallic industry and underground construction, the level of injuries during blasting is $2-22 \%$ and the level of injuries during the collapse of the sides of the ledges is 4 $16 \%$ of the total number, with the number of performers of blasting within 10 thousand people.

In order to reduce the seismic manifestation of the explosion, improve the quality of blasting operations, reduce accidents and injuries, recently used initiation elements without the use of electric current, capable of changing the deceleration between explosions in a wide range. These are domestic systems of non-electric explosion initiation SINV, Iskra, Korshun, the use of which in enterprises reaches more than 10 million sets.

It is advisable to select the deceleration intervals between explosions of charge groups and change the detonation schemes after operational processing of the results of real explosions. To obtain operational information, it is necessary to create a mobile seismic recorder. Based on the information obtained, it is possible to make objective decisions that minimize the seismic effect of the explosion on the rock mass and increase the safety of mining enterprises, industrial and economic facilities in the area of the explosion.

In connection with the above, the processes of short-delayed detonation of groups of charges using modern means of initiation need further study and research to minimize the seismic manifestation of short-delayed detonation and represent an important current safety problem.

Reducing the seismic impact on buildings and structures is provided by reducing the overall intensity of seismic radiation by more fully using the energy of the blast wave to crush the rock and control the spectral composition of seismic vibrations.

The most promising direction for improving earthquake resistance is the seismic insulation of buildings. Seismic isolation involves detuning the vibration frequencies of the building from the prevailing frequencies of the impact. This is what reduces the mechanical energy received by the structure from the base. Specialists of Kazakhstan and foreign countries have proposed various devices of seismic isolation systems and dampers of vibration energy of structures, as well as systems using alloys that store the volume state, and other 'intelligent' systems.

The following trends are observed in the world: the first is the use of pure seismic insulation of buildings, which is usually arranged in the lower floors: rubber-metal supports of various modifications with low and high damping, with a core of lead and without it, with the use of various materials. There are also friction sliding supports of the pendulum type. Both supports are widely used in the world. The second direction of application of damping (vibration damping), which is known for a very long time and is constantly being improved.

For high-rise construction, as a rule, a combination is used: seismic insulation is placed in the lower floor, and damping is installed along the height of the building. Now manufacturers 
offer a variety of dampers: metal, liquid, there are special alloys with memory, special damping walls. The latter devices, although relatively expensive, are quite effective.

One of the most common methods of earthquake-resistant construction is the construction of buildings on a foundation with a large margin of load-bearing strength. In order to successfully resist the seismic impact, scientists are also developing new building materials. In particular, they created a new type of concrete, called 'elastic' concrete. It, as the name suggests, is characterized by increased elasticity and flexibility. An interesting feature of the material can be considered the ability to self-heal under the influence of rain or snow. These unusual properties of concrete are provided by the addition of minerals that are part of seashells. The resulting load cracks in this amazing concrete, over time, are tightened, and the strength of the material remains unchanged.

However, some building materials known since ancient times are also earthquake resistant. In particular, such materials include clay. Another innovation in the construction materials industry: the use of high-strength reinforcement in the construction of buildings and structures. Currently, the production of earthquake-resistant reinforcement of strength class $500 \mathrm{MPa}$ is carried out.

Since in [40] it was decided to implement the information system '3D-quarry' as a web application, the implementation of the module 'EIA' was also decided to implement on the basis of the previously adopted concept:

- the concept of Software as a Service (SaaS) or 'program as a service' for the end user;

- data opacity for the resource administrator or storing only data encrypted with the user's personal password in the database;

- selectable modularity of the application for the end user;

- transparency of the methods used for the end user.

Using the SaaS cloud computing model allows you to reduce the cost of software maintenance on the user side by eliminating self-administration of the resource, provide users with ease of operation due to the cross-platform nature of the resource and independence from the hardware and software resources used on the client side. So, from the client's point of view, both classic computers, tablets, and smartphones can be used as equipment. So, in our opinion, only this can provide the client with an annual savings of at least 1000 USD. The only software resource required for operation is a browser, which is included in the basic configuration of any operating system, and an Internet connection.

An additional requirement for implementing this approach is the implementation of an adaptive interface (for the screen resolution of the device used by the user). However, at the current stage, this solution is not implemented in all modules.

Important factors for choosing SaaS as a promotion model were the economic parameters for the resource owner of the 3D-quarry system: the convenience of controlling the monetization of the resource, the convenience of protecting against the use of unauthorized copies compared to the Application Service Provider (ASP) concept, and the elaboration of mechanisms for 'promotion' and promotion of the resource as a web site. Also, in our opinion, this decision will help to reduce the share of pirated software in the market of Kazakhstan.

The opacity of the data for the resource administrator and the storage of the data in the encrypted master key of the data allows the end user to transparently implement the secrecy of his commercial activities. The use of strong encryption algorithms allows you to protect your data both from external attacks on the resource, and from possible potential attempts to 'pressure' the resource owner in order to disclose customer information. As symmetric encryption algorithms, the AES algorithm with client - side encryption/decryption is of 
interest, and as hashing algorithms, MD5 or SHA3 is of interest. The only drawback of this solution is a significant increase in the computational load, both on the client's hardware resources and on the communication channel. However, the increased performance of both stationary and mobile computing devices, as well as the widespread introduction of highspeed communication networks, at least based on the LTE standard, allow us to successfully solve the problem of transmitting and processing large amounts of data.

The modular architecture allows you to flexibly manage the necessary structure of the resource, build it up and upgrade it (including with the possibility of attracting third-party developers), as well as evaluate the contribution of each of the modules to the profitability of the resource and, accordingly, quite simply and transparently determine the share of the total profit for the developer of each of the modules.

The transparency of the methods used for the end user with the generation of a pdf document with calculations allows an experienced end user to 'see' alternative career development paths offered by the resource, if necessary, to form an evidence base for making certain decisions, and an inexperienced user to learn from the examples of calculations performed by the resource,

The operation of all modules that implement the processing of client data is assumed in the mode of end-to-end data encryption using the AES algorithm. For encryption, a master encryption/decryption key is used for user groups.

The on-screen forms of the module are shown in Tables 2-4. To perform calculations, the user selects the typical values of the reference data (or specifies them for this direct user).

TABle 2. CALCUlation OF GROSS EMISSIONS OF HARMFUl SUBSTANCES DURING DRILLING OPERATIONS

\begin{tabular}{|c|c|c|}
\hline \multicolumn{3}{|c|}{ Initial data } \\
\hline Parameter & Unit of measurement & Value \\
\hline Hardness of rocks & & $f>14$ \\
\hline Drilling rig type & & SBSH-250MNA-32 \\
\hline Number of drilling rigs & & 5 \\
\hline Drilling rig productivity & Running meter/hour & 8.33 \\
\hline $\begin{array}{l}\text { Volumetric productivity of the } \\
\text { drilling rig }(Q)\end{array}$ & Cubic meter/hour & 0.41 \\
\hline Nominal working time fund & Days & 280 \\
\hline $\begin{array}{l}\text { The number of shifts per day of } \\
\text { operation of drilling rigs }\end{array}$ & & 2 \\
\hline $\begin{array}{l}\text { Nominal fund of machine tools } \\
\text { per year }(T)\end{array}$ & Hours & 6720 \\
\hline Type of explosive & & Granulit C-6M \\
\hline $\begin{array}{l}\text { The volume of the blasted rock } \\
\text { mass }\end{array}$ & $\begin{array}{l}\text { Cubic meter/running meter of } \\
\text { the well }\end{array}$ & 40 \\
\hline $\begin{array}{l}\text { The volume of the blasted rock } \\
\text { mass }\end{array}$ & Cubic meter/year & 11195520 \\
\hline
\end{tabular}


Table 3. The Result pF the Calculations (Data From the Software)

\begin{tabular}{|c|c|c|c|}
\hline \multicolumn{4}{|c|}{ Initial data } \\
\hline \multicolumn{2}{|c|}{ Parameter } & Unit of measurement & Value \\
\hline \multirow{3}{*}{$\begin{array}{l}\text { Specific dust release per } \\
\text { cubic meter of cuttings, } \\
q\end{array}$} & $\begin{array}{l}\text { Air-water method of dust } \\
\text { collection }\end{array}$ & \multirow{3}{*}{ Kilogram/cubic meter } & 3.50 \\
\hline & Air method of dust collection & & 4.40 \\
\hline & No dust collection & & 110.40 \\
\hline \multicolumn{2}{|c|}{$\begin{array}{l}\text { Coefficient considering the moisture content of the material, } \\
K_{2}\end{array}$} & & 0.10 \\
\hline \multirow{3}{*}{$\begin{array}{l}\text { Gross dust emission } \\
\text { during drilling, } \\
M_{1}\end{array}$} & $\begin{array}{l}\text { Air-water method of dust } \\
\text { collection }\end{array}$ & \multirow{3}{*}{ Kilogram/year } & 480.73 \\
\hline & Air method of dust collection & & 606.14 \\
\hline & No dust collection & & 30417.41 \\
\hline
\end{tabular}

TABLE 4. AUXILIARY COMPONENT 'REFERENCE BOOK' (IN RELATION TO THE SBSH-250 MACHINE)

\begin{tabular}{llllll}
\hline \multicolumn{1}{c}{ Drilling rig type } & SBSH-250MNA-32 & & & \\
\hline & Coals & $\begin{array}{l}\text { Limestone, } \\
\text { shales }\end{array}$ & $\begin{array}{l}\text { Siltstone, } \\
\text { lightly } \\
\text { cemented }\end{array}$ & $\begin{array}{l}\text { Medium } \\
\text { density } \\
\text { siltstone }\end{array}$ & $\begin{array}{l}\text { Sandstones } \\
\text { (strong) }\end{array}$ \\
\hline $\begin{array}{l}\text { Rock strength on the scale of Pr. M. M. } \\
\text { Protodyakonov }\end{array}$ & $\mathrm{f}=1 \ldots .2$ & $\mathrm{f}=2 \ldots 4$ & $\mathrm{f}=4 \ldots 6$ & $\mathrm{f}=6 \ldots 8$ & $\mathrm{f}=8 \ldots 10$ \\
\hline $\begin{array}{l}\text { Average volume productivity of the drilling } \\
\text { machine, cubic meter/hour }\end{array}$ & 2.18 & 2.02 & 1.80 & 1.50 & 1.29 \\
\hline The means of suppression or dust collection & Specific dust emission, kilogram/cubic meter & \\
\hline Water-air dust suppressor & 0.8 & 1.5 & 1.9 & 3.0 & 3.5 \\
\hline Dry dust collection & 1.0 & 1.9 & 2.5 & 3.9 & 4.4 \\
\hline $\begin{array}{l}\text { Without means of dust suppression, } \\
\text { unacceptable or emergency operation of the } \\
\text { machine }\end{array}$ & 24.1 & 48.3 & 62.5 & 96.5 & 110.4 \\
\hline
\end{tabular}

The initial testing of the system modules was performed on the local server. For this purpose: apache server 2.4.28, php language 7.1.10, MySQL DBMS 5.0.12. As a client, use a notebook with a screen resolution of $1366 \times 768$. Other system features: Intel Core $i 7-3517 U$ processor, $8 \mathrm{~Gb}$ RAM, Windows 10 Pro operating system. Testing was carried out in the browsers Google Chrome, Mozilla, IE, Opera.

The test tests of the module on the data of the quarries of JSC ' $S S G P O$ ' and the manual calculations carried out according to the selected methods showed a $100 \%$ coincidence of the results.

Further development of the module is aimed at introducing multilingualism mechanisms, accumulating the results of calculations with the rating factors of the summer and winter seasons, implementing a graphical display of the dynamics of changes in the indicators of negative factors, as well as developing a decision-making support system for the development of measures to reduce negative impacts.

The first issue of the 3D Quarry system's EIA module was submitted to the production server, and students continued testing the university's specialized educational programs on desktop computers, laptops, and smartphones. 


\section{Discussions}

The results of the analysis of the investigated methods of assessing impacts of the quarries:

- First, it should be noted that existing predictive methods based on the use of average annual values of emissions of pollutants for the company as a whole without regard to change of physico-mechanical properties of rocks in mining areas, mining and climatic conditions.

- Secondly, scientific studies on the negative impact of quarries with comparative factors of the summer and winter period of the year, seasonal changes in temperature and humidity, wind speed and direction for quarries and sections, as a rule, are not carried out.

Accordingly, a possible further development of the module for a comprehensive assessment of the impact of the quarry, it is possible to use it to obtain a dynamic picture of the inflow of pollutants into the environment and develop a module based on it for the dynamic formation of strategic and tactical measures to reduce the negative impact of the quarry on the environment.

\section{Conclusions}

The main requirements for the rational use and protection of mineral resources are:

- strict compliance with design decisions;

- maintaining the established geological survey documentation;

- ensuring and controlling the complete extraction of raw materials;

- reliable accounting of the reserves extracted and left in the subsurface, drawing up annual plans for the development of mining operations;

- protection of mineral deposits from flooding, flooding, fires and other factors that reduce the quality of minerals and the industrial value of deposits or complicate their development;

- not allowing excessive losses, dilution and selective mining of minerals;

- compliance with the requirements for the safe conduct of mining operations related to the use of subsurface resources;

- the production of blasting operations below the level of underground water in a clamped environment, the development of minerals by the non-explosive method;

- Prevention of subsurface pollution by industrial waste or wastewater.

As a result of the conducted research, methods were identified, and algorithms were developed for assessing the environmental impact of open-pit mining of mineral deposits. Based on the results obtained, the 'EIA' module, consisting of the submodules 'Water Basin', 'Atmosphere', and 'Subsurface', was developed within the framework of the '3D-quarry' system.

As a result of the study, the following conclusions are made:

- conducted a critical analysis of international and national EIA methodologies and developed EIA approaches that meet both national and international standards;

- the developed algorithms and software implementation of the EIA module are adequate to the selected methods;

- integration of the EIA module into the 3D-quarry system allows improving the quality of mining planning, assessing environmental risks and developing timely measures to reduce negative impacts; 
- the concept of monetization of the application in general and the module in particular as a SaaS solution has been developed and mechanisms for calculating the economic efficiency of the module within the application based on usage statistics have been developed;

- to protect against unauthorized access (NSD) and use (NSI), mechanisms for endto-end encryption of all user data based on the international AES encryption standard on the client side, storage of authenticating information in the database based on the MD5 hashing algorithm (with the possibility of further replacement with SHA3) and opacity of client data for the system administrator are implemented;

- $\quad$ for the convenience of the client, the mechanism of transparency of the performed calculations is implemented by generating a pdf document.

Thus, it can be argued that the developed software allows you to solve an important task for the economy and ecology of Kazakhstan to automate calculations of the impact of the developed open fields on the environment and perform import substitution of software of foreign IT companies working in the field of subsurface use, which is one of the priorities of the country's development.

\section{REFERENCES}

[1] Smirnyakova V.V. Ocenka vozdejstviya predpriyatij ugol'noj otrasli na okruzhayushchuyu prirodnuyu sredu (Assessment of the impact of coal industry enterprises on the environment.). Proceedings of the 9th International conference on the problems of mining, construction and energy 2013:2(2):255-259. (in Russian)

[2] Instrukciya po provedeniyu ocenki vozdejstviya na okruzhayushchuyu sredu. Prikaz Ministra ohrany okruzhayushchej sredy Respubliki Kazahstan ot 28 iyunya 2007 goda № 204-p (Instructions for Conducting an Environmental Impact Assessment. Order of the Minister of Environmental Protection of the Republic of Kazakhstan dated June 28, 2007 No. 204-p) [Online]. [Accessed 14.01.2021]. Available: https://adilet.zan.kz/rus/docs/V070004825

[3] Poslanie glavy gosudarstva Kasym-ZHomarta Tokaeva narodu Kazahstana 1 sentyabrya 2020 goda (Message from the head of state Kassym-Zhomart Tokayev to the people of Kazakhstan on September 1, 2020) [Online]. [Accessed 14.01.2021]. Available: http://www.akorda.kz/ru/addresses/addresses_of_president/poslanie-glavy-gosudarstvakasym-zhomarta-tokaeva-narodu-kazahstana-1-sentyabrya-2020-g (in Russian)

[4] Zarubin M., et al. Developing information systems of operation schedules to stabilize the grade of a mineral. Mining of Mineral Deposits 2017:11(4):59-70. https://doi.org/10.15407/mining11.04.059

[5] Minin A. A. Geologicheskie posledstvija gornorudnogo proizvodstva (Geological consequences of mining production.). Energiya: Ekonomika, Tehnika, Ekologiya 2010:3:49-51. (in Russian)

[6] The US National Environmental Policy Act (NEPA). USA, 1969.

[7] Council Directive of 27 June 1985 on the assessment of the effects of certain public and private projects on the environment (85/337/EEC). Official Journal 1985:47.

[8] Maksimenko Yu. L. Maksimenko, Yu. L. Ocenka vozdejstviya na okruzhayushchuyu sredu: Posobie dlya praktikov (Environmental Impact Assessment: A Handbook for Practitioners.). Moscow: REFIA, 1996. (in Russian)

[9] United Nations. Convention on Environmental Impact Assessment in a Transboundary Context. Geneva: UN, 1991.

[10] Yelyubaev Zh. S. Legal Regulation of Subsoil Use and Investment in the Countries of Caspian and Black Sea Regions. Presented at the Conference 'Upstream Development in the Caspian and Black Sea Regions', Baku, Azerbaijan, 2014.

[11] Kodeks Respubliki Kazahstan O nedrah i nedropol'zovanii (s izmeneniyami i dopolneniyami po sostoyaniyu na 09.03.2021 g.) (Code of the Republic of Kazakhstan On Subsoil and Subsoil Use (with amendments and additions as of 09.03.2021.)). [Online]. [Accessed 15.03.2021]. Available: https://online.zakon.kz/Document/?doc_id=31764592 (in Russian)

[12] Ekologicheskij kodeks Respubliki Kazahstan ot 2 yanvarya 2021 goda № 400-VI ZRK (Environmental Regulation of the Republic of Kazakhstan dated January 2, 2021 No. 400-VI ZPK). [Online]. [Accessed 14.01.2021]. Available: https://adilet.zan.kz/rus/docs/K2100000400

[13] Zemel'nyj kodeks Respubliki Kazahstan ot 20 iyunya 2003 goda № 442. obnovlennyj s izmeneniyami na: 01.01 .2021 (Land Code of the Republic of Kazakhstan dated June 20, 2003 No. 442. updated with changes as of: 01.01.2021.) [Online]. [Accessed 14.01.2021]. Available: https://adilet.zan.kz/rus/docs/K030000442_(in Russian) 
[14] Vodnyj kodeks Respubliki Kazahstan ot 9 iyulya 2003 goda № 481-II (s izmeneniyami i dopolneniyami po sostoyaniyu na 02.01.2021 g.) Water Code of the Republic of Kazakhstan dated July 9, 2003 No. 481-II (with amendments and additions as of 01/02/2021).). [Online]. [Accessed 14.01.2021]. Available: https://online.zakon.kz/document/?doc_id=1042116 (in Russian)

[15] Iljin V. I. Tekhnologicheskie processy i sposoby ochistki proizvodstvennyh stochnyh vod (Technological processes and methods of industrial wastewater treatment. Moscow: RHTU, 2014.

[16] Pavlov D. V., Gogina E. S. Sovremennaya resursosberegayushchaya sistema oborotnogo vodosnabzheniya galvanicheskogo proizvodstva (Modern resource-saving water recycling system for galvanic production.). Vestnik MGSU 2013:10:175-182.

[17] Pavlova I. V., Postnikova I. N. Zashchita prirodnyh vod ot tekhnogennyh zagryaznenij: uchebnoe posobie dlya studentov napravlenij podgotovki bakalavrov i magistrantov 'Himicheskaya tekhnologiya' i 'Tekhnosfernaya bezopasnost'" (Protection of natural waters from technogenic pollution: a textbook for students in the areas of training bachelors and undergraduates 'Chemical technology' and 'Technosphere safety'.). Nizhny Novgorod: Nizhny Novgorod state technical university n. a. R.E. Alekseev, 2015. (in Russian)

[18] Lesin $\mathrm{Yu}$. V. Massoperenos dispersnyh chastic pri fil'tracii vody v krupnozernistyh sredah. Fiziko-tekhnicheskie problemy razrabotki poleznyh iskopaemyh (Mass transfer of dispersed particles during water filtration in coarsegrained media). Fiziko-Tehnicheckie Problemi Razrabotki Poleznih Iskopaemih 2010:1:92-96. (in Russian)

[19] Lesin Yu. V. Ochistka stochnyh vod v tekhnogennyh porodnyh massivah (Wastewater treatment in technogenic rock masses.). Mining informational and analytical bulletin 2010:OVZ:119-124. (in Russian)

[20] Tyulenev M. A. Perenos zagryaznyayushchih veshchestv pri fil'tracii stochnyh kar'ernyh vod vo vskryshnyh porodah (Transfer of pollutants during filtration of pit wastewater in overburden.). Vestnik Kuzbasskogo Gosudarstvennogo Gosudarstvennogo Tehnicheskogo Universiteta 2011:2:22-30. (in Russian)

[21] Kalnins S. N. et al. Applicability of Combined Project Evaluation Methodology to EIA Projects. Energy Procedia 2016:95:424-428. https://doi.org/10.1016/j.egypro.2016.09.052

[22] Bajcinovci B. Environment Quality: Impact from Traffic, Power Plant and Land Morphology, a Case Study of Prishtina. Environmental and Climate Technologies 2017:19(1):65-74. https://doi.org/10.1515/rtuect-2017-0006

[23] Bajcinovci B. Environmental and Climate Dilemma: Coal for Heating or Clean Air for Breathing: A Case of Prishtina. Environmental and Climate Technologies 2019:23(1):41-51. https://doi.org/10.2478/rtuect-2019-0003

[24] Baird J., et al. Emergence of Collaborative Environmental Governance: What are the Causal Mechanisms? Environmental Management 2019:63(1):16-31. https://doi:10.1007/s00267-018-1105-7

[25] Kubule A., Komisarova T., Blumberga D. Optimization Methodology for Complete Use of Bio-resources. Energy Procedia 2017:113:28-34. https://doi.org/10.1016/j.egypro.2017.04.009

[26] Astahov A. S. Ekologicheskaya bezopasnost' i effektivnost' prirodopol'zovaniya (Environmental safety and efficiency of nature management.). Moscow: MGU, 2003.

[27] Rodzkin A., et al. The Assessment of Cost of Biomass from Post-Mining Peaty Lands for Pellet Fabrication. Environmental and Climate Technologies 2018:22(1)118-131. https://doi.org/10.2478/rtuect-2018-0008

[28] Diaz F., Cilinskis E. Use of Multi-Criteria TOPSIS Analysis to Define a Decarbonization Path in Colombia. Environmental and Climate Technologies 2019:23(3):110-128. https://doi.org/10.2478/rtuect-2019-0083

[29] Kuzmin S., et al. Development of a New Environmentally-Friendly Technology for Transportation of Mined Rock in the Opencast Mining. Environmental and Climate Technologies 2020:24(1):341-356. https://doi.org/10.2478/rtuect2020-0019

[30] Kadnikova O., et al. Ecological Feasibility of Applying Technology in Recycling Garment and Knitwear Production. Environmental and Climate Technologies 2019:23(2):291-309. https://doi.org/10.2478/rtuect-2019-0069

[31] Rzhevskij V. V. Otkrytye gornye raboty, tekhnologiya i kompleksnaya mekhanizaciya: uchebnik dlya studentov vuzov, obuchayushchihsya po specialjnosti 'Tekhnologiya i kompleksnaya mekhanizaciya otkrytoj razrabotki mestorozhdenij poleznyh iskopaemyh' (Open pit mining, technology and integrated mechanization: a textbook for university students studying in the specialty 'Technology and integrated mechanization of open pit mining of mineral deposits'.). Moscow: LIBROKOM, 2010. (in Russian)

[32] Trubeckoj K. N., et al. Spravochnik. Otkritie gornie raboti (Directory. Open pit mining.). Gornoe Bjuro, 1994. (in Russian)

[33] Trubeckoj K. N. Osnovnye napravleniya i puti resheniya problem resursosberezheniya pri kompleksnom osvoenii nedr s zemnoj poverhnosti (The main directions and ways of solving the problems of resource conservation in the complex development of subsoil from the earth's surface.). Mining informational and analytical bulletin 2011:1:433-446. (in Russian)

[34] Chanturiya V. A., Bunin I. Z. Pulsed power nanotechnologies for disintegration and breaking up of refractory precious metals. Nanobiotechnology in energy, environment and electronics methods and applications. Singapore: Jenny Stendford Publishing, 2014:41-66.

[35] Metodika rascheta vrednyh vybrosov (sbrosov) i ocenki ekologicheskogo ushcherba pri ekspluatacii razlichnyh vidov kar'ernogo transporta (Methodology for calculating harmful emissions (discharges) and assessing environmental damage during the operation of various types of open pit transport.). Moscow: National Mining Research Center - A. A. Skochinsky Institute of Mining, 1994. (in Russian) 
[36] Metodika rascheta vrednyh vybrosov (sbrosov) dlya kompleksa oborudovaniya otkrytyh gornyh rabot (na osnove udel'nyh pokazatelej (Methodology for calculating harmful emissions (discharges) for a complex of equipment for open pit mining (based on specific indicators).). Luberci: Minenergo, 2016:12-55. (in Russian)

[37] Normativno-pravovaya baza prirodopol'zovaniya i ohrany okruzhayushchej sredy (Regulatory framework for the use of natural resources and environmental protection) [Online]. [Accessed 15.03.2021]. Available: http://scibook.net/uchebniki-ekologii_1295/normativno-pravovaya-baza-prirodopolzovaniya-57916.html (in Russian)

[38] Zarubin M., Zarubina V. Results of using neural networks for technological processes control of iron mill. Energy Procedia 2016:95:512-516. https://doi.org/10.1016/j.egypro.2016.09.077

[39] Zarubin M., et al. 3D-Quarry: Digitization of The Geological Model of Deposit Based on A Semi-Structured Data Model. Proceedings of the 36th International Business Information Management Association (IBIMA) 2020:11621170.

[40] Yue D., et al. Network-based robust $\mathrm{H} \infty$ control of systems with uncertainty. Automatica 2005:41(6):999-1007. https://doi.org/10.1016/j.automatica.2004.12.011

[41] Gorban A. N., et al. Neuroinformatics. Novosibirsk: Science, Siberian office of the Russian Academy of Sciences, 1998.

[42] Tsaregorodtsev V. The View of architecture and the requirement to the neurosimulator for the solution of modern industrial tasks. Proceedings of the 11th All-Russian seminar 'Neuroinformatics and its appendices' 2003:171-175.

[43] Tsaregorodtsev V. G. Simplification of neural networks kk-purposes, ideas and methods. Neyrokompyyutera 2002:4:513.

[44] Zarubin M. Results of development optimized adaptive ACS on neural network for mining. Journal of Chemical Technology and Metallurgy 2016:4(51):473-482. 